Article

\title{
Novel catalytic and effluent decolorization functionalities of sol-gel immobilized Pleurotus ostreatus IBL-02 manganese peroxidase produced from bio-processing of wheat straw
}

\author{
Muhammad Asgher, Bazgha Aslam, Hafiz Muhammad Nasir Iqbal* \\ Industrial Biotechnology Laboratory, Department of Chemistry and Biochemistry, University of Agriculture, Faisalabad, Pakistan
}

A R T I C L E I N F O

Article history:

Received 19 May 2013

Accepted 25 June 2013

Published 20 September 2013

\section{Keywords:}

Pleurotus ostreatus IBL-02

Bio-catalysis

Manganese peroxidase

Immobilization

Sol-gel

Textile effluent

Decolorization

\begin{abstract}
A B S T R A C T
Solid state bio-processing of wheat straw was carried out through an indigenous fungal strain Pleurotus ostreatus IBL-02 under pre-optimized fermentation conditions. The maximum activity, $692 \pm 12 \mathrm{U} / \mathrm{mL}$, of the industrially important manganese peroxidase (MnP) enzyme was recorded after five days of still culture incubation. The crude MnP was 2.1-fold purified with a specific activity of $860 \mathrm{U} / \mathrm{mg}$ after purification on a Sephadex-G-100 gel column. On native and SDS-PAGE electrophoresis gels, the purified MnP fraction was a single homogenous band of $45 \mathrm{kDa}$. An active fraction of MnP was immobilized using hydrophobic sol-gel entrapment comprising tetramethoxysilane (T) and propyltrimethoxysilane (P) at different T:P molar ratios. Characterization revealed that after 24 $\mathrm{h}$ incubation at varying $\mathrm{pH}$ and temperatures, the $\mathrm{MnP}$ fraction immobilized at a T:P ratio of 1:2 in the sol-gel retained $82 \%$ and $75 \%$ of its original activity at $\mathrm{pH} 4$ and $70{ }^{\circ} \mathrm{C}$, respectively. The optimally active fraction at a 1:2 T:P ratio was tested against $\mathrm{MnSO}_{4}$ as a substrate to determine the kinetic catalytic constants $K_{\mathrm{M}}$ and $V_{\max }$. To explore the industrial applicability of $P$. ostreatus IBL-02 $\mathrm{MnP}$, both the free and immobilized MnP were used for the decolorization of four different textile industrial effluents. A maximum of $100 \%$ decolorization was achieved for the different textile effluents within the shortest time period. A lower $K_{\mathrm{M}}$, higher $V_{\max }$, hyper-activation, and enhanced acidic and thermal resistance up to $70{ }^{\circ} \mathrm{C}$ were the novel catalytic features of the sol-gel immobilized MnP, suggesting that it may be a potential candidate for biotechnological applications particularly for textile bioremediation purposes.
\end{abstract}

(C) 2013, Dalian Institute of Chemical Physics, Chinese Academy of Sciences. Published by Elsevier B.V. All rights reserved.

\section{Introduction}

Lignocellulosic biomass is a major renewable resource of potentially fermentable carbohydrates but is mostly discarded in the form of pre-harvest and post-harvest agricultural losses, and waste from food processing industries. The lignocellulosic wastes are present in abundance and therefore, are of great value as raw materials for the production of industrially important enzymes. It has been established that white rot fungi (WRF), a group of generally robust microbes, can produce ex- tracellular ligninolytic enzymes comprising lignin peroxidase (LiP), manganese peroxidase (MnP), and laccase that are involved in the degradation of lignin as well as in bio-remediation processes [1-3]. During recent years, there has been a great interest in the potential applications of $\mathrm{MnP}$ in bio-pulping and bio-bleaching as well as in bio-remediation processes [1-4].

MnPs are extracellular glycoproteins with an iron protoporphyrin IX (heme) prosthetic group mostly secreted in multiple forms during secondary metabolism [5]. $\mathrm{Mn}^{2+}$ functions as a mediator for $\mathrm{MnP}$ where $\mathrm{MnP}$ catalyzes the $\mathrm{H}_{2} \mathrm{O}_{2}$ dependent 
oxidation of $\mathrm{Mn}^{2+}$ to $\mathrm{Mn}^{3+}$ that subsequently forms complexes with different chelators like pyrophosphate malonate, oxalate, L-tartrate, oxaloacetate, L-malate, and methylmalonate, lowmolecular-mass diffusible mediators, which non-specifically oxidize a variety of phenolic and non-phenolic substances including lignin and toxic pollutants [2].

Textile effluents contain several types of chemicals including real dye residues that are toxic, carcinogenic, mutagenic, and pose serious health hazards to the entire living ecosystem. An eco-friendly treatment method of textile waste effluents is still a major environmental concern of the modern world [6]. In spite of the existing physical and chemical technologies, which are usually expensive and commercially unattractive, biological processes provide an alternative cost effective and eco-friendly approach that can be applied to wide range of dye containing industrial effluents $[4,6]$. Industrial applications of enzymes in most cases involve the use of continuous reactors that require immobilized bio-catalysts in order to improve process efficiency through improvements in enzyme stability, reusability and controlled product release. A variety of immobilization techniques have been investigated to develop immobilized bio-catalysts [5]. However, among the different immobilization methods, gel entrapment is preferred because gel polymers are non-toxic and do not swell in aqueous or organic solvents, thus preventing the leaching of the entrapped enzyme and denaturation of its native conformation $[3,7,8]$.

WRF has the ability to degrade contaminants by virtue of its extracellular ligninolytic enzymes [3-6,9]. During the last few years, we have demonstrated considerable improvement in many processes related to lignocellulose biotechnology and triggered in-depth studies of lignocellulosic materials, ligninolytic microorganisms, and their enzymes. Therefore, in this context, the capability of the indigenously isolated MnP to degrade/decolorize different textile dyes containing industrial waste effluents was investigated for its use in biotechnological applications particularly for textile bioremediation purposes.

\section{Experimental}

\subsection{Chemicals and lignocellulosic substrate}

Propyltrimethoxysilane $(\mathrm{P})$, tetramethoxysilane $(\mathrm{T})$, polyvinyl alcohol, Sephadex-G-100, and standard protein markers were purchased from Sigma-Aldrich (USA). Agricultural waste wheat straw was collected from the Student Research Farm, University of Agriculture Faisalabad, Pakistan. The substrate was chopped, dried $\left(60^{\circ} \mathrm{C}\right)$, ground to a fine particle size and stored in polyethylene plastic bags to avoid free moisture until further use. For decolorization studies, four different dyes containing textile industry effluents, i.e., Nishat textile (NIT), K\&N textile (KIT), Sitara textile (SIT), and Crescent textile (CRT) were collected on-site from local textile industries in Faisalabad, Pakistan.

\subsection{Microorganism and preparation of inoculum}

A pure culture of the indigenous fungal strain P. ostreatus
IBL-02 was raised on potato dextrose agar (PDA) slants at $\mathrm{pH}$ 4.5 and $28{ }^{\circ} \mathrm{C}$. Homogenous spore inoculum was prepared by growing the fungus for $5 \mathrm{~d}$ in the Kirk's basal nutrient medium in the presence of an additional 1\% (w/v) Millipore filtered sterile glucose solution to develop inoculums with $1 \times 10^{6}$ $1 \times 10^{8}$ spore $/ \mathrm{mL}$. The main constituents of the medium were ammonium tartrate $(0.22 \mathrm{~g} / \mathrm{L}), \mathrm{KH}_{2} \mathrm{PO}_{4}(0.21 \mathrm{~g} / \mathrm{L}), \mathrm{MgSO}_{4} \cdot 7 \mathrm{H}_{2} \mathrm{O}$ $(0.05 \mathrm{~g} / \mathrm{L}), \mathrm{CaCl}_{2} \cdot \mathrm{H}_{2} \mathrm{O}(0.01 \mathrm{~g} / \mathrm{L})$, thiamine $(0.001 \mathrm{~g} / \mathrm{L})$, and Tween-80 (10 mL/L).

\subsection{Production and extraction of $M n P$}

P. ostreatus IBL-02 was grown in solid state fermentation (SSF) using a wheat straw based fermentation medium under pre-optimized growth conditions. The culture flasks $(500 \mathrm{~mL})$ contained $5 \mathrm{~g}$ wheat straw, moistened (66\% w/w moisture) with Kirk's salt medium that was supplemented with glycerol and urea as an inexpensive carbon and nitrogen source in a ratio of 25:1 (C:N) and $1 \mathrm{mmol} / \mathrm{L} \mathrm{MnSO}_{4}(1 \mathrm{~mL})$ as optimal nutritional factors. The SSF medium was autoclaved, inoculated (5 $\mathrm{mL}$ fresh fungal spores) and allowed to ferment at $30^{\circ} \mathrm{C}$ in a still culture incubator (Sanyo, Japan). After $7 \mathrm{~d}$ of fermentation, $100 \mathrm{~mL}$ of distilled water was added to all of the fermented cultures and the flasks were shaken at $120 \mathrm{r} / \mathrm{min}$ for $30 \mathrm{~min}$ [10]. The contents were filtered and the filtrates were centrifuged at $3000 \mathrm{~g}$ for $10 \mathrm{~min}$ (Sanyo, Japan). The supernatants were pooled and used as a crude extract for the MnP activity assay, purification, and immobilization purposes.

\subsection{Determination of MnP activity and protein content}

MnP activity was measured by adopting the methodology previously described [2,6]. The MnP activity was measured against a reagent blank at $270 \mathrm{~nm}\left(€_{270}=11590 \mathrm{~mol}^{-1} \mathrm{~L} \mathrm{~cm}^{-1}\right.$, UV 2000, Hitachi, Germany). The recorded activities were expressed as $\mathrm{U} / \mathrm{mL}$, where one unit of activity was defined as the amount of enzyme required to produce a unit increase in the absorbance at a specific wavelength $(\mathrm{nm})$ per $\mathrm{mL}$ of the reaction mixture. To determine the protein content of the sample, the Bradford microassay was used with bovine serum albumin as the standard [11].

\subsection{Purification of MnP}

Purification of MnP was carried out by ammonium sulfate fractionation ( $85 \%$ saturation), followed by dialysis and gel filtration chromatography using a Sephadex-G-100 column $(2 \times 25 \mathrm{~cm})$ as described previously [2]. Phosphate buffer $(100$ mmol/L) with $0.15 \mathrm{~mol} / \mathrm{L} \mathrm{NaCl}$ was used as the elution buffer and the flow rate was maintained at $0.5 \mathrm{~mL} / \mathrm{min}$. Up to 20 pooled fractions were collected, concentrated by ultra-filtration and used to determine molecular mass, enzyme activity as well as the protein content as described in section 2.4.

\subsection{Native and SDS-PAGE}

The purified and lyophilized sample was dissolved in a 
minimum amount of $50 \mathrm{mmol} / \mathrm{L}$ malonate buffer, and subjected to $12 \%$ native PAGE and $10 \%$ SDS-PAGE using a vertical minigel electrophoresis apparatus (V-GES, Wealtec Corporation, USA) to determine sample purity and approximate mass of MnP according to the method of Laemmli [12].

\subsection{Immobilization of purified $M n P$}

Sol-gels of different hydrophobic characters were prepared using varying T:P ratios $(1: 1,1: 2,1: 5,1: 10)$ in ascending order by adopting the methodology as described previously [4], with minor modifications. Specific activity and protein content of entrapped enzymes (in gels of different hydrophobicities) were determined. The entrapped enzyme having the highest specific activity and immobilization efficiency was selected for further characterization in comparison to the purified free MnP extract.

\subsection{Characterization of free and immobilized $M n P$}

\subsubsection{Effect of $p H$}

To determine the effect of $\mathrm{pH}$, the $\mathrm{pH}$-activity profile of $\mathrm{MnP}$ was determined over a range of $\mathrm{pH} 3$ to 9 on free and gel entrapped MnP. Both the free and gel entrapped MnPs were incubated separately at $30{ }^{\circ} \mathrm{C}$ without substrate using the following buffers: sodium malonate, $\mathrm{pH} 3.0$ and 4.0; citrate phosphate, pH 5.0 and 6.0; sodium phosphate, $\mathrm{pH} 7.0$ and 8.0 , potassium carbonate buffer, $\mathrm{pH} 9.0$.

\subsubsection{Effect of temperature}

Effect of varying temperatures on the free and immobilized MnP was also studied by adopting the methodology as described previously [8]. The free and gel entrapped MnPs were incubated in sodium malonate buffer at $\mathrm{pH} 4.0$ for $24 \mathrm{~h}$ at temperatures ranging from $25-75^{\circ} \mathrm{C}$.

\subsubsection{Determination of $K_{\mathrm{M}}$ and $V_{\max }$}

The effect of varying substrate concentrations on free and immobilized MnPs was investigated. Activities of free and immobilized enzymes were determined using varying concentrations (0.1-1.0 mmol/L) of $\mathrm{MnSO}_{4}$ as the substrate. The data were then used to construct reciprocal plots using a Lineweaver-Burk transformation of the Michaelis-Menten equation by plotting the reciprocals of the initial reaction rates $\left(1 / V_{0}\right)$ against the reciprocals of the respective substrate concentrations $[1 / \mathrm{S}]$.

\subsection{Decolorization of real textile industry effluents}

Decolorization of individual effluents was determined by a reduction in optical density at the wavelength of maximum absorbance $590 \mathrm{~nm}\left(\lambda_{\max }\right)$. The working conditions of a single continuous operation included two parallel batches of triplicate flasks containing either $10 \mathrm{~mL}$ of free or $5 \mathrm{~g}$ of sol-gel entrapped $\mathrm{MnP}$ with $10 \mathrm{~mL}$ of $50 \mathrm{mmol} / \mathrm{L}$ sodium malonate buffer and $100 \mathrm{~mL}$ of individual textile effluents. The flasks were incubated at $30^{\circ} \mathrm{C}$ in a shaking incubator $(120 \mathrm{r} / \mathrm{min})$ for $5 \mathrm{~h}$.

\subsection{Statistical analysis}

All enzyme assays were performed in triplicate, and the data were statistically analyzed. The means and standard errors of the means (mean \pm SE) were calculated for each treatment and the SE values have been displayed as Y-error bars in figures.

\section{Results and discussion}

\subsection{MnP production and purification}

MnP was produced from an indigenous strain of $P$. ostreatus IBL-02 on wheat straw under pre-optimized fermentation conditions. A maximum MnP activity of $612 \pm 12 \mathrm{U} / \mathrm{mL}$ was recorded when $5 \mathrm{~mL}$ of the fungal inoculum was inoculated into medium nutritionally supplemented with glycerol and urea at a $25: 1 \mathrm{C} / \mathrm{N}$ ratio, $1 \mathrm{~mL}$ of $1 \mathrm{mmol} / \mathrm{L}$ tween-80 as a surface active agent, and $1 \mathrm{~mL}$ of $1 \mathrm{mmol} / \mathrm{L} \mathrm{MnSO}_{4}$ as a mediator. Ligninolytic enzyme production is strongly affected by the nature and amount of the nutrients and physical elements of the growth substrate. Different fungal species have particular responses to various nutrients and show different growth and enzyme activity patterns depending on the substrate $[8,10]$. The purification summary for P. ostreatus IBL-02 MnP is shown in Table 1. After Sephadex-G-100 filtration, the specific activity of MnP increased to $860 \mathrm{U} / \mathrm{mg}$ with 2.1-fold purification. Previously we have reported the successful use of Sephadex G-100 gel filtration column chromatography for the purification of various fungal enzymes, i.e., cellulases, protease, and various ligninolytic enzymes from different fungal cultures including Trichoderma harzianum, Aspergillus niger, Trametes versicolor IBL-04, and Schizophyllum commune IBL-06 [2-4,6,8,10,13]. In another study, MnP from Phanerochaete sp. was salted out at $65 \%$ $\left(\mathrm{NH}_{4}\right)_{2} \mathrm{SO}_{4}$ saturation with 2.6-fold MnP purification [14].

\subsection{Native and SDS-PAGE}

The purified MnP was resolved on native and SDS-PAGE with a molecular weight of $45 \mathrm{kDa}$ relative to the standard molecular weight markers (Fig. 1). The molecular mass of $P$. ostreatus IBL-02 MnP was within the range of molecular weights

Table 1

Purification summary for P. ostreatus IBL-02 MnP.

\begin{tabular}{|c|c|c|c|c|c|}
\hline Purification step & Total volume (mL) & Enzyme activity (U/mL) & Protein content $(\mathrm{mg} / \mathrm{mL})$ & Specific activity (U/mg) & Purification fold \\
\hline Crude enzyme & 300 & 188700 & 468.0 & 403 & 1 \\
\hline$\left(\mathrm{NH}_{4}\right)_{2} \mathrm{SO}_{4}$ precipitation & 20 & 10240 & 19.60 & 522 & 1.3 \\
\hline Dialysis & 20 & 9960 & 16.2 & 615 & 1.5 \\
\hline Sephadex-G-100 & 14 & 3612 & 4.2 & 860 & 2.1 \\
\hline
\end{tabular}




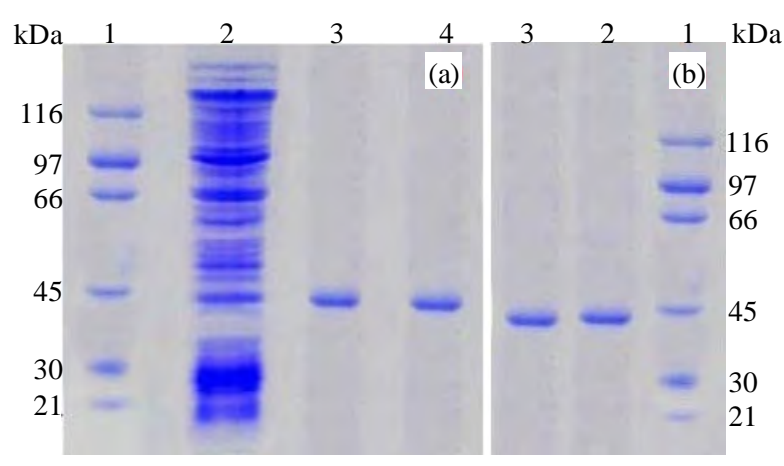

Fig. 1. SDS (a) and native (b) PAGE of MnP produced from P. ostreatus IBL-02. The molecular mass of the purified MnP was estimated in comparison to standard weight markers (standard protein markers, 21-116 kDa; Sigma, USA). The protein bands were visualized by staining with Coomassie Brilliant Blue G-250 (Sigma, USA) after documentation.

varying between 32 and $75 \mathrm{kDa}$ commonly found for the MnP family $[2,15]$. The molecular weights for MnPs from B. pumilus and Paenibacillus sp. as determined by SDS-PAGE were 25 and $40 \mathrm{kDa}$, respectively, whereas MnP from Irpex lacteus was a single polypeptide of $53.2 \mathrm{kDa}$ on SDS-PAGE [16]. As shown in our previous study, MnP from T. versicolor IBL-04 was a homogenous monomeric protein as shown by its single band of $43 \mathrm{kDa}$ on SDS-PAGE [2].

\subsection{Immobilization of P. ostreatus IBL-02 MnP}

Specific activities of free and immobilized MnP and the percent immobilization efficiency in different gels are shown in Table 2. The specific activity of immobilized MnP was higher than that of the free enzyme and it increased as the T:P ratio hydrophobicity of the sol-gels increased. However, with increasing hydrophobic character (higher T:P ratios, i.e., 1:5 and $1: 10$ ), the specific activity of immobilized MnP significantly decreased, possibly because of the diffusion limitation barrier created by increasing the hydrophobic nature of the gel. Maximum specific activity ( $975 \mathrm{U} / \mathrm{mg}$ ) was observed for the MnP fraction entrapped in the sol-gel matrix at a 1:2 of T:P ratio. Thus, it was selected for textile waste effluent decolorization studies. Entrapment of enzyme in sol-gels involves an adsorption phenomenon that has been reported as the best method for immobilization of laccase [7]. Previously, we reported that entrapment of LiP from P. chrysosporium and Trametes versicolor IBL-04 in sol-gels caused hyper-activation but an increase

Table 2

Specific activities of free and immobilized MnPs with immobilization efficiency.

\begin{tabular}{|c|c|c|c|}
\hline \multirow{2}{*}{$\begin{array}{l}\text { Gel precursors } \\
\text { (T:P) molar ratio }\end{array}$} & \multicolumn{2}{|c|}{ Specific activity a $(\mathrm{U} / \mathrm{mg})$} & \multirow{2}{*}{$\begin{array}{l}\text { Immobilization } \\
\text { efficiencyb (\%) }\end{array}$} \\
\hline & Free $\mathrm{MnP}$ & Immobilized MnP & \\
\hline$\overline{1: 1}$ & 660 & 722 & 88.3 \\
\hline $1: 2$ & 860 & 975 & 93.6 \\
\hline 1:5 & 735 & 885 & 72.1 \\
\hline $1: 10$ & 522 & 748 & 58.4 \\
\hline
\end{tabular}

a Calculated in $\mathrm{U} / \mathrm{mg}$ of protein.

${ }^{\mathrm{b}}$ Difference between the enzyme loaded and the enzyme in supernatant after washing.

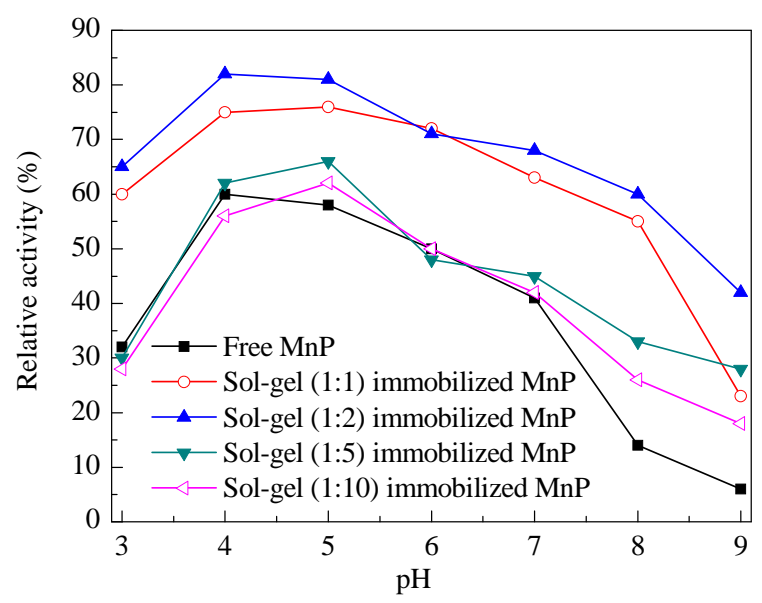

Fig. 2. Effect of pH on free and sol-gel immobilized MnPs.

in hydrophobic character above certain optimum limits caused a decrease in LiP activity $[3,17]$. In addition, the results obtained by the sol-gel entrapment for the presently reported MnP immobilization are in the range of those attained by other methods such as covalent bonding of the enzyme on siliceous cellular foams, sepa beads and amine-terminated magnetic nano-composite by a glutaraldehyde cross-linking method $[18,19]$.

\subsection{Characterization of free and immobilized MnPs}

\subsubsection{Effect of $p H$ on free and immobilized $M n P$}

Characterization revealed that after $24 \mathrm{~h}$ incubation at varying pHs, the MnP fraction immobilized in the sol-gel at a 1:2 (T:P) ratio retained $82 \%$ of its original activity at $\mathrm{pH} 4$ (Fig. 2). All four MnP fractions entrapped in varying T:P ratio gels showed broader $\mathrm{pH}$ ranges than that of the free MnP. The method of immobilization and ionic or hydrogen bonding and secondary interactions between enzyme and gel particles may be responsible for this broader $\mathrm{pH}$ stability profile under an acidic environment. Earlier studies reported the maximum activities of MnPs from different WRF were observed at pHs from 5.5 to $6.5[15,16]$. At a $\mathrm{pH}$ value more or less than 4 , the $\mathrm{MnP}$ activity decreased. Our results are in accordance with immobilization process of D'Annibale et al. [20] who showed that the ligninase enzymes of $L$. edodes are stable over a $\mathrm{pH}$ range of 2.5-4.0. In support of our findings, Qiu et al. [7] found that immobilized as well as free laccase showed similar $\mathrm{pH}$-activity profiles because of the clear surface of the nanoporous gold immobilization support used.

\subsubsection{Effect of temperature on free and immobilized $M n P$}

The MnP immobilized in the sol-gel at a 1:2 (T:P) ratio retained $75 \%$ of its original activity at $70{ }^{\circ} \mathrm{C}$ as compared to the free and other immobilized fractions (Fig. 3). The order of thermostability was 1:2 MnP >1:1 MnP > 1:5 MnP > 1:10 MnP. In an earlier study, Asgher et al. [17] reported that the optimum temperature for gel entrapped lignin degrading enzymes ranged in $40-55^{\circ} \mathrm{C}$. Most of the previously reported MnPs were found to lose their activities at temperatures around $60{ }^{\circ} \mathrm{C}[21]$. 


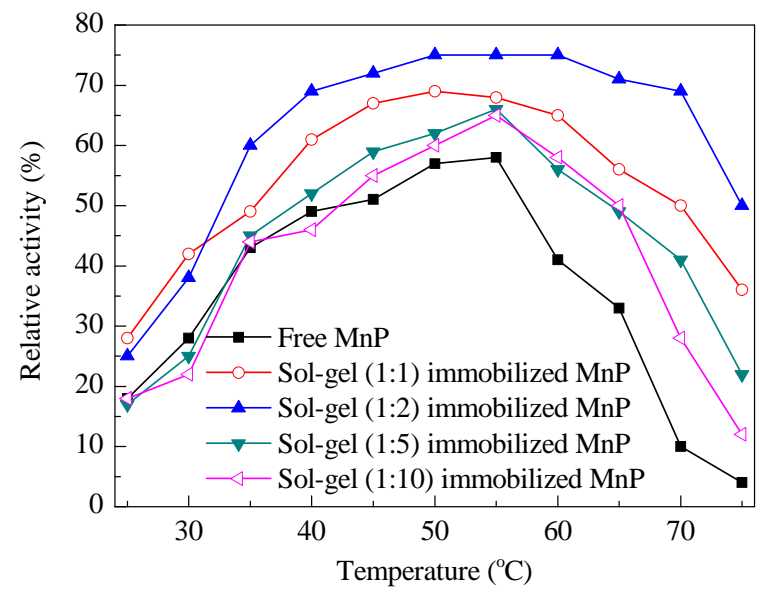

Fig. 3. Effect of temperature on free and sol-gel immobilized MnP.

MnP from Irpex lacteus was stable over $30-40{ }^{\circ} \mathrm{C}$ [16], whereas MnP from $P$. chrysosporium was completely inactivated within $15 \mathrm{~min}$ at $60^{\circ} \mathrm{C}[22]$.

\subsubsection{Effect of substrate concentration: Determination of $K_{M}$ and $V_{\max }$}

Sol-gel matrix immobilization enhanced the substrate affinity and catalytic efficiency of $\mathrm{MnP}$ as confirmed by its lower $K_{\mathrm{M}}$ $(27 \mathrm{mmol} / \mathrm{L})$ and higher $V_{\max }$ values $(227 \mathrm{U} / \mathrm{mg}$ ) for the immobilized enzyme compared to the free MnP that had values of $K_{\mathrm{M}}$ (54 mmol/L) and $V_{\max }(182 \mathrm{U} / \mathrm{mg}$ ) (Fig. 4). Results shown in Fig. 4 indicated that MnP entrapped at a 1:2 of T:P ratio had more affinity for its substrate, but its interaction decreased with a further increase in gel hydrophobicity. In previous studies, different $K_{\mathrm{M}}$ values for MnP from different WRF strains such as Bjerkandera sp. and Phanerochaete chrysosporium (45-51.9 $\mu \mathrm{mol} / \mathrm{L})$ [23], and Irpex lacteus (46.7 $\mu \mathrm{mol} / \mathrm{L})$ [24],

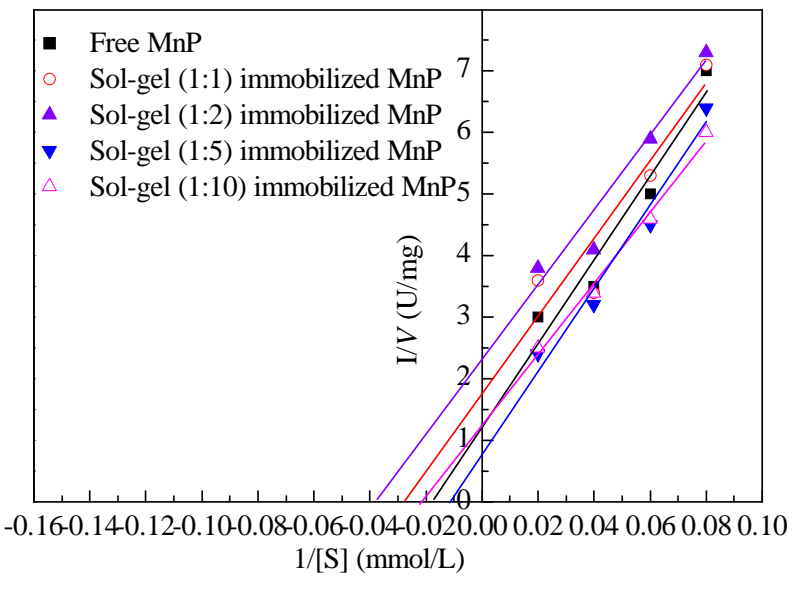

Fig. 4. Lineweaver-Burk reciprocal plot: $K_{\mathrm{M}}$ and $V_{\max }$ for free and immobilized MnP. Standard quartz cuvettes having path length of $1 \mathrm{~mm}$ with exterior width, length, and height $(W \times L \times H)$ dimensions of $12.5 \mathrm{~mm} \times$ $3.5 \mathrm{~mm} \times 45 \mathrm{~mm}$ were used to determine the values of kinetic parameters for free and immobilized MnP. Both free and immobilized MnP was incubated for $15 \mathrm{~min}$ at $30{ }^{\circ} \mathrm{C}$ in sodium malonate buffer of $\mathrm{pH} 4.5$ before carrying out standard enzyme activity assays. Lineweaver-Burk plot created with Microsoft Excel Windows updated version 7 via nonlinear curve fitting, using varying concentrations (0.1-1.0 mmol/L) of $\mathrm{MnSO}_{4}$ as a substrate.

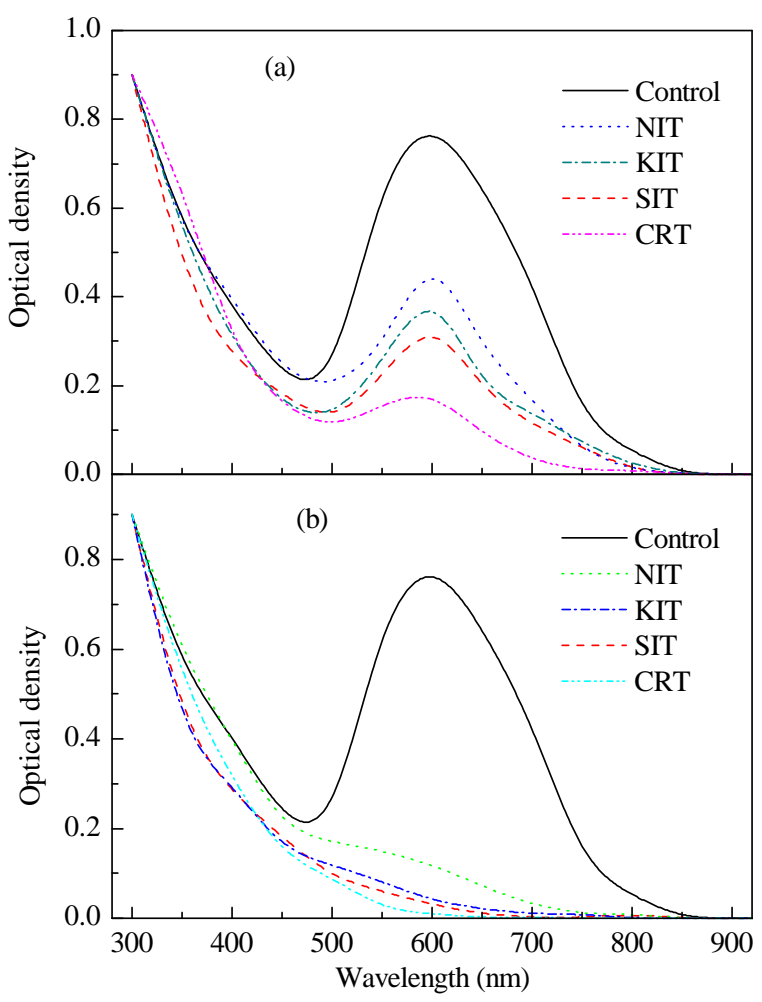

Fig. 5. UV-Vis absorption spectra of textile effluents obtained after $5 \mathrm{~h}$ treatment with free MnP (a) and 1:2 of T:P immobilized MnP (b).

have been reported. The difference in $K_{\mathrm{M}}$ values of MnPs from $P$. ostreatus IBL-02 and other reported fungal species can be explained on the basis of genetic variability and substrate specificities among different species.

\subsection{Decolorization of real textile industry effluents}

CRT, a textile industrial effluent, was $100 \%$ decolorized, followed by SIT (98.5\%) after $5 \mathrm{~h}$ of incubation with an immobilized MnP as compared to its free counterpart (Fig. 5). In a previous study, Coriolus versicolor was found to decolorize Arzoo textile industry effluents to $84 \%$ in $3 \mathrm{~d}$ [25]. The variation in effluent composition results in the differences in the decolorization by enzyme extracts from different fungi $[17,26]$. In this context, the present sol-gel matrix-entrapped $\mathrm{MnP}$ seems to be suitable as an enzyme for bioremediation in the textile industry.

\section{Conclusions}

The catalytic features of the P. ostreatus IBL-02 MnP makes it a multipurpose enzyme suitable for a variety of biotechnological applications. Characterization results revealed that the MnP fraction immobilized in the sol-gel at a 1:2 (T:P) ratio retained $82 \%$ and $75 \%$ of its original activity at $\mathrm{pH} 4$ and $70{ }^{\circ} \mathrm{C}$, respectively. The novel catalytic features of the sol-gel immobilized MnP included a lower $K_{\mathrm{M}}$, higher $V_{\max }$, hyper-activation, and enhanced acidic and thermal stability up to $70{ }^{\circ} \mathrm{C}$, suggesting that it is a potential candidate for biotechnological applications particularly for textile bioremediation purposes. 


\title{
Graphical Abstract
}

\author{
Chin. J. Catal., 2013, 34: 1756-1761 doi: 10.1016/S1872-2067(12)60647-0
}

\section{Novel catalytic and effluent decolorization functionalities of sol-gel immobilized Pleurotus ostreatus IBL-02 manganese peroxidase produced from bio-processing of wheat straw}

Muhammad Asgher, Bazgha Aslam, Hafiz Muhammad Nasir Iqbal*

University of Agriculture, Pakistan

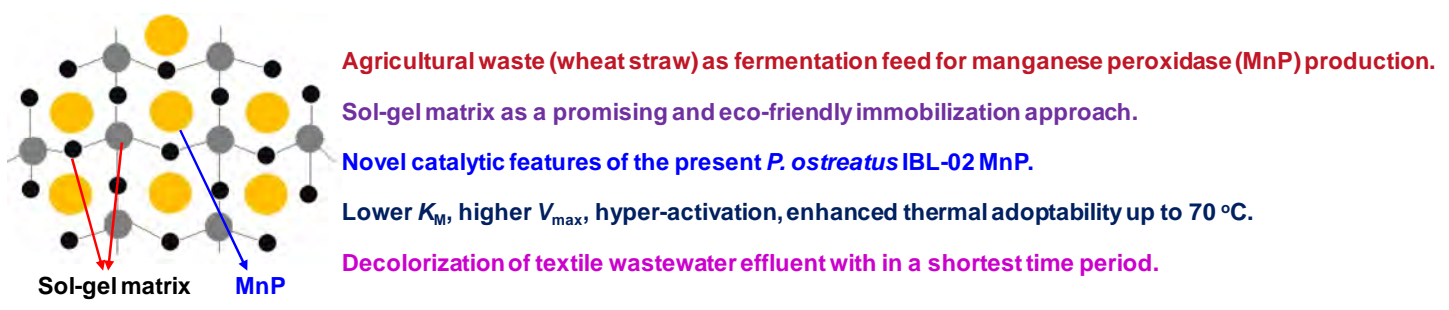

Agro-industrial based lignocellulosic waste material i.e. wheat straw was used as a fermentation feed stuff for MnP production. A promising and eco-friendly approach was adopted to immobilize the purified MnP into the sol-gel matrix network. To explore the textile industrial applicability, the immobilized MnP was tested against real dye containing textile effluents.

\section{Acknowledgements}

The present investigation was a part of a research project entitled "the development of immobilized ligninolytic enzymes for industrial applications" supported by Higher Education Commission (HEC), Islamabad, Pakistan. For providing financial support, HEC is thankfully acknowledged.

\section{References}

[1] Papinutti V L, Forchiassin F. J Food Eng, 2007, 81: 54

[2] Asgher M, Iqbal H M N. BioResources, 2011, 6: 4317

[3] Asgher M, Iqbal H M N, Irshad M. BMC Biotechnol, 2012, 12: 46

[4] Asgher M, Kamal S, Iqbal H M N. Chem Cent J, 2012, 6: 110

[5] Cheng X B, Jia R, Li P S, Tu S Q, Zhu Q, Tang W Z, Li X D. Enzyme Microb Technol, 2007, 41: 258

[6] Asgher M, Iqbal H M N. Chin Chem Lett, 2013, 24: 344

[7] Qiu H J, Xu C X, Huang X R, Ding Y, Qu Y B, Gao P J. J Phys Chem C, 2009, 113: 2521

[8] Iqbal H M N, Asgher M. Protein Pept Lett, 2013, 20: 591

[9] Saratale R G, Saratale G D, Chang J S, Govindwar S P. J Taiwan Inst Chem Eng, 2011, 42: 138

[10] Iqbal H M N, Asgher M, Bhatti H N. BioResources, 2011, 6: 1273

[11] Bradford M M. Anal Biochem, 1976, 72: 248
[12] Laemmli U K. Nature, 1970, 227: 680

[13] Ahmed I, Zia M A, Iftikhar T, Iqbal H M N. BioResources, 2011, 6: 4505

[14] Rajan A, Kurup J G, Abraham T E. Braz Arch Biol Technol, 2010, 53: 555

[15] Baborova P, Möder M, Baldrian P, Cajthamlová K, Cajthaml T. Res Microbiol, 2006, 157: 248

[16] Shin K S, Kim Y H, Lim J S. J Microbiol, 2005, 43: 503

[17] Asgher M, Asad M J, Bhatti H N, Legge R L. World J Microbiol Biotechnol, 2007, 23: 525

[18] Xiao H-Y, Huang J, Liu C, Jiang D-S. Trans Nonferrous Met Soc China, 2006, 16: s414

[19] Nwagu T N, Aoyagi H, Okolo B N, Yoshida S. J Mol Catal B, 2012, 78: 1

[20] D’Annibale A, Stazi S R, Vinciguerra V, Giorannozzi Sermanni G. J Biotechnol, 2000, 77: 265

[21] Lopos de Oliveira P, Duarte M C T, Ponezi A N, Durrant L R. Braz J Microbiol, 2009, 40: 354

[22] Hoshino F, Kajino T, Sugiyama H, Asami O, Takahashi H. FEBS Lett, 2002, 530: 249

[23] Palma C, Martínez A T, Lema J M, Martínez M J. J Biotechnol, 2000, 77: 235

[24] Sklenar J, Niku-Paavola M-L, Santos S, Man P, Kruus K, Novotny C. Enzyme Microb Technol, 2010, 46: 550

[25] Asgher M, Azim N, Bhatti H N. Biochem Eng J, 2009, 47: 61

[26] Spahn C, Minteer S D. Recent Pat Eng, 2008, 2: 195 